Sains Malaysiana 49(10)(2020): 2453-2464

http://dx.doi.org/10.17576/jsm-2020-4910-11

\title{
Strain Selection for Growth Enhancement of Wild and Cultivated Eucheumatoid Seaweed Species in Indonesia
}

(Pemilihan Strain untuk Peningkatan Pertumbuhan Spesies Rumpai Laut Eucheumatoid Liar dan Ternakan di Indonesia)

\author{
Andi Parenrengi*, Symon Dworjanyn, Rachman Syah, Petrus Rani Pong-Masak \& Mat Fahrur
}

\begin{abstract}
A poor seed quality is one of the main constraints to provide a fast growth for seaweed production. It is hoped that seaweed strain selection may lead to production of a high quality seed, resulting in an enhanced growth rate of cultivated seaweeds. The study aimed to obtain a fast growing seaweed strain through proper selection. Three types of base strains were selected: A wild type of Eucheuma denticulatum from Nusa Tenggara Timur (NTT), and two types of cultivated seaweed of Kappaphycus alvarezii from Takalar and Gorontalo, respectively. The collected seaweeds were grown in Laikang Bay using the long line method. The strain selection was based on the daily growth rate (DGR) parameter. The seaweeds were cultivated for 30 days to produce seed, and selected seed material was used for the next cycle for three cycles. The results show that the selected seaweed strains had a higher DGR compared with nonselected (internal control) seed from each of the original forms. DGR of the selected and control seed of the Takalar,

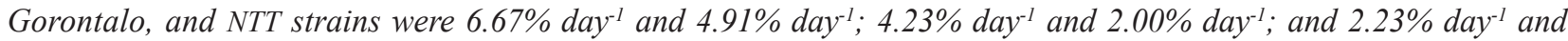
$1.20 \%$ day ${ }^{-1}$, respectively. The selection technique increased the DGR up to $1.68 \%$ day-1 for three cultivation cycles, while carrageenan content was up to $4.7 \%$ higher than the internal control. In conclusion, the best strain for cultivation in Laikang Bay was that of selected from Takalar.
\end{abstract}

Keywords: Eucheumatoid seaweed; growth enhancement; strain selection; wild and cultivated seaweed

ABSTRAK

Kualiti benih yang rendah merupakan salah satu kekangan utama yang melambatkan pertumbuhan rumpai laut. Pemilihan strain rumpai laut dapat menjurus kepada penghasilan benih yang berkualiti tinggi, sekaligus mempertingkat kadar pertumbuhan kultur rumpai laut. Kajian ini bertujuan untuk mendapatkan strain rumpai laut yang dapat tumbuh dengan cepat melalui pemilihan yang sesuai. Tiga jenis strain asas telah dipilih; jenis liar Eucheuma denticulatum dari Nusa Tenggara Timur (NTT) dan dua jenis kultivar rumpai laut Kappaphycus alvarezii masing-masing dari Takalar dan Gorontalo. Rumpai laut yang dikumpulkan dibiakkan di Laikang Bay dengan menggunakan kaedah garisan panjang. Pemilihan strain dilakukan berdasarkan kadar pertumbuhan harian (DGR). Rumpai laut dikultur selama 30 hari untuk menghasilkan benih sebelum digunakan pada kitaran seterusnya selama tiga kitaran. Hasil menunjukkan strain rumpai laut yang dipilih mempunyai DGR yang lebih tinggi berbanding benih bukan pilihan (kawalan dalaman). DGR bagi benih terpilih dan kawalan daripada strain Takalar, Gorontalo dan NTT masing-masing adalah $6.67 \%$ hari ${ }^{-1}$ dan $4.91 \%$ hari $^{-1}$; 4.23\% hari $^{-1}$ dan 2.00\% hari $^{-1}$; dan 2.23\% hari ${ }^{-1}$ dan $1.20 \%$ hari ${ }^{-1}$. Teknik pemilihan ini meningkatkan DGR sehingga 1.68\% hari-1 bagi tiga kitaran penanaman, manakala kandungan karagenan bertambah sehingga $4.7 \%$ berbanding kawalan dalaman. Kesimpulannya, strain terbaik untuk penanaman di Laikang Bay ialah strain terpilih dari Takalar.

Kata kunci: Pemilihan strain; peningkatan pertumbuhan; rumpai laut Eucheumatoid; rumpai laut liar dan terkultivasi

\section{INTRODUCTION}

Seaweed is an important component of marine ecosystems, along with mangroves and coral reefs, and can be viewed from two perspectives which are ecological value and economic uses. Seaweeds are exported either as raw material (fresh or dried seaweeds) or in processed form (e.g. semi-refined chips/carrageenan and refined carrageenan). Indonesia is one of the largest producers of seaweed in the world, especially the red seaweeds comprising Kappaphycus alvarezii and Eucheuma denticulatum (Parenrengi 2013). Wild and cultivated forms of $E$. denticulatum, $K$. alvarezii, and $K$. striatum are primary sources of the commercially valuable hydrocolloid 
carrageenan. The trade name for the farmed commercial eucheumatoid species E. denticulatum is 'spinosum', which produces iota-carrageenan, while 'cottonii' is the commercial name for the two farmed Kappaphycus species that produce kappa-carrageenan (Ask \& Azanza 2002). Seaweed cultivation has expanded rapidly to meet the growing demand of raw material for industrial purposes, either for domestic uses or for export markets. Since 2011, Indonesia has become a global leader in carrageenan (eucheumatoid species) production. In 2016, Indonesian seaweed production reached 11,631,000 MT, while the Philippines produced 1,405,000 MT and Korea produced 1,351,000 MT (FAO 2018).

The seaweed species $K$. alvarezii, previously known as Eucheuma cottonii, belongs to the Rhodophyceae, and several strains have become intensively cultivated in coastal waters due to the potential market opportunities. This commodity has become a mainstay of the drive to increase production because it has advantages such as manual production systems that do not require complicated technology and can be developed as a labor-intensive activity, and a short production cycle (45 days) that can quickly generate income. Furthermore, post-harvest handling is easy and inexpensive, does not require special equipment, and the dried product can be stored for a long time.

Indonesia has decided to focus on seaweed cultivation as a main target for seaweed-related industrialization. About 2.1 million hectares have been allocated for seaweed cultivation. In 2008, Indonesia harvested about 1.8 million tons of seaweeds (wet weight). In view of the future potential, Indonesian government has expanded the seaweed cultivation areas to 2.6 million hectares in 2010 (Parenrengi 2013). Due to the mass production of raw seaweed, several studies have been conducted to support the seaweed industrialization programme. These include studies on site suitability for seaweed culture (Hasnawi et al. 2013; Mustafa et al. 2017; Pongmasak et al. 2010; Radiarta et al. 2012, Suhaimi et al. 2012), genetic characterization (Parenrengi et al. 2007, 2006; Sulaeman et al. 2007; Suryati et al. 2013), seed production by conventional and tissue culture technique (Amini \& Parenrengi 1995; Mulyaningrum et al. 2013; Rajamuddin et al. 2010; Suryati et al. 2015, 2007), effects of temperature and light on photosynthesis (Lideman et al. 2014), cultivation methods (Pongmasak \& Tjaronge 2010), pests and diseases (Pongmasak 2010), and development strategies for seaweed cultivation (Erlania \& Radiarta 2014; Hadie \& Hadie 2012; Paena et al. 2010; Priyono $\&$ Andriyanto 2012). However, there are few studies on growth rate enhancement through strain selection techniques.

To date, one of the problems faced by seaweed farmers is the low quality of seed obtained from the cultivated seaweed, as indicated by slow growth (Pongmasak et al. 2011; Porse \& Rudolph 2017). This condition has led to a decrease in production of raw seaweed. Genetic improvement and growth rate enhancement are both important as alternative ways to produce high quality seed for cultivation. To address this problem, this study was conducted to obtain fast growing strains of eucheumatoid seaweed species through strain selection. Meanwhile, the long-term objective was to improve seaweed production in Indonesia through the utilization of seaweed seed from selected strains.

\section{MATERIALS AND METHODS}

\section{SAMPLE COLLECTION}

Eucheumatoid seaweed samples were collected from the wild in the waters of Alor, Nusa Tenggara Timur (NTT), and from several cultivated seaweed strains from Gorontalo and Takalar. The wild seaweed strain from NTT was morphologically identified as the species Eucheuma denticulatum, while the cultivated seaweed from Gorontalo was Kappaphycus alvarezii, of a strain popularly known as kulit buaya, because the thallus physically resembles crocodile skin. The Takalar strain was also K. alvarezii, of a strain commonly cultivated in Takalar Regency. The seaweed from NTT and Gorontalo were transported to the study site in Laikang Bay, Takalar, South Sulawesi and underwent acclimatization through cultivation in that location for one month to obtain parent stock (Figure 1) prior to selection process. The same cultivation protocol for preparing the parent stock was also applied to the Takalar strain collected from the surrounding of the study site.

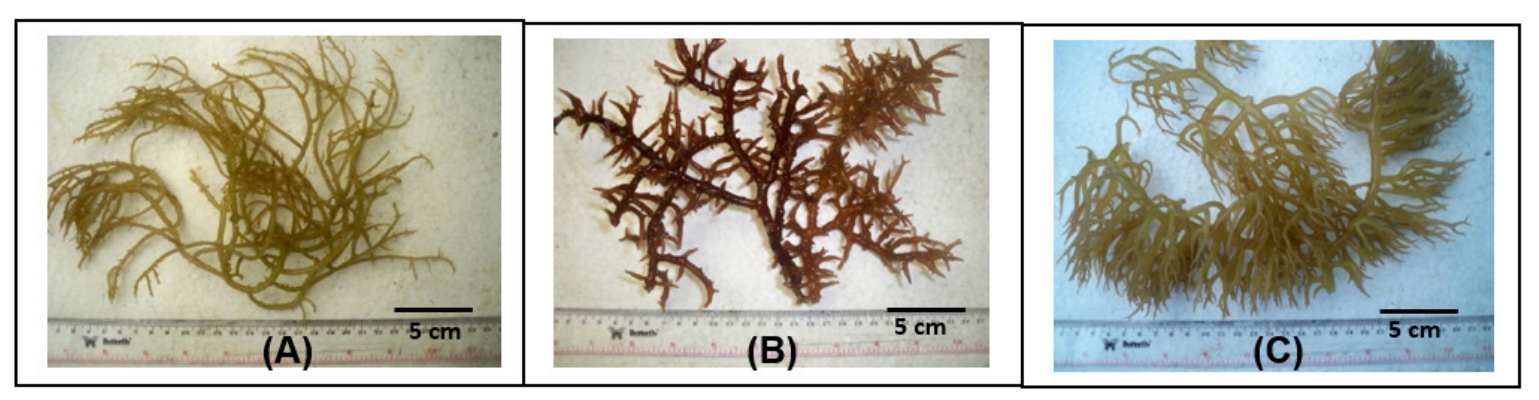

FIGURE 1. Parent stock of three eucheumatoid seaweed species: wild strain from NTT (A), cultivated 'kulit buaya' strain from Gorontalo, and (C) strain from Takalar 


\section{SEAWEED CULTIVATION FOR STRAIN SELECTION}

The selection of cultivation site was based on the data and information of seasonal seaweed growing. The cultivation technique was carried out by constructing the main framework for long line cultivation in an area of $50 \times 30$ $\mathrm{m}$. The different seaweed strains were cultivated using a long line technique as follows. Seed (clumps) with initial weight of $50 \mathrm{~g}$ were tied to nylon rope with a distance of $15 \mathrm{~cm}$ between clumps. For each strain, 10 long line ropes with 230 clumps per rope were prepared and cultivated. Seed from all cultivars was cultivated for 30 days to produce seed for the next 30 days cycle of cultivation or generation. The parent stock was named as generation-0 $\left(\mathrm{G}_{0}\right)$ and the next cycle was generation- $1\left(\mathrm{G}_{1}\right)$, and so-on, until the $\mathrm{n}^{\text {th }}$ generation $\left(\mathrm{G}_{\mathrm{n}}\right)$. After 30 days of cultivation, each clump was weighed to determine the average daily growth rate (DGR) for each strain. For each strain (cultivar/ form), the clumps with the highest DGR of top ten percent (10\% DGRmax) were selected to provide seed for the next propagation cycle, while cuttings-off from the other clumps were used as an internal control (without selection). The seaweed cultivated by farmers around the study site was used as an external control. This procedure was performed until a stable growth rate was reached during several cycles. The selection protocol was based on that developed by Pongmasak et al. (2011), and the procedure is illustrated in Figure 2. The setting of the top ten percent in terms of growth rate as a selection criterion was based on previous research on seaweed selection aiming to improve growth rate (Pongmasak et al. 2013).

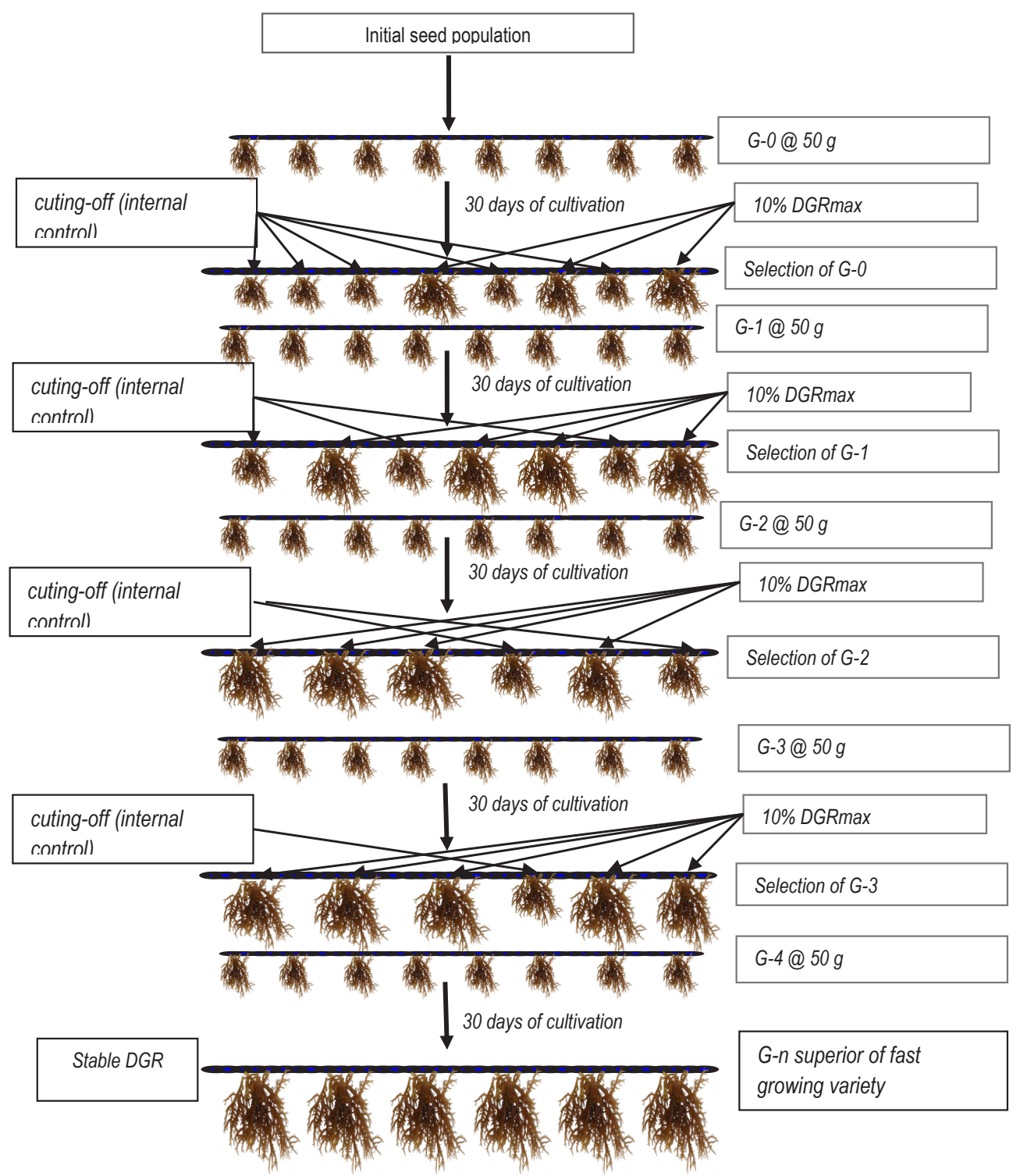

FIGURE 2. The seaweed selection protocol procedures, based on growth rate as a criterion (illustration adapted from Pongmasak et al. 2011) 


\section{DAILY GROWTH RATE (DGR) AND WATER QUALITY PARAMETERS}

Daily growth rate was measured randomly for three longlines (for three cycles as replicates) from 10 long-lines for every 30 days of cultivation cycle, as described previously. Water quality parameters, including nitrate, phosphate, $\mathrm{pH}$, and salinity, were measured for every 30 days.

\section{CARRAGEENAN CONTENT AND GEL STRENGTH}

Carrageenan content and gel strength were analysed after the 30 days of cultivation of the third cycle (G$3)$. Carrageenan content was determined based on the conventional method developed by Mulyaningrum et al. (2009). Seaweed samples were washed with fresh water to remove salt and contaminants and then soaked for 2 days. The samples were first heated in an autoclave at $120^{\circ} \mathrm{C}$ for 15 min using water as a solvent, with a ratio of seaweed $(\mathrm{g})$ : water $(\mathrm{mL})$ of $1: 45$. A second heating was performed in a heater at a temperature of $100{ }^{\circ} \mathrm{C}$ for 30 min until the seaweed was completely soft. The sample was blended and extracted using hot water with a ratio of 1:30, and the sample was then filtered. The filtered sample was coagulated with propanol at a ratio of 1:2.5 to produce a gel. The gel was dried at ambient temperature. Once completely dry, the sample was measured to obtain the weight of carrageenan. The carrageenan gel strength was measured using texture analyser apparatus based on the protocol in FMC Corp. (1977).

\section{STATISTICAL ANALYSIS}

To determine the effect of selection, the difference between the DGR of selected seaweeds, internal controls and external controls was analysed by random variance analysis at a significance level of 0.05 . The difference in carrageenan content and gel strength between selected seaweeds and internal controls was statistically analysed using the t-student test.

\section{RESULTS AND DISCUSSION}

\section{DAILY GROWTH RATE (DGR)}

Based on the DGR of the three strains, the Takalar strain showed the best performance after the strain selection procedure (Figure 3). The Takalar selected seaweed strain grew faster than both the internal and external controls, with DGR ranging from $6.49-6.83 \%$ day $^{-1}$ for selected seaweed, while the DGR of the internal control and external controls were 4.87-4.93\% day $^{-1}$ and 3.33$3.95 \%$ day $^{-1}$, respectively. The DGR of the Gorontalo selected seaweed strain was $2.95-5.07 \%$ day $^{-1}$, while the internal control was $0.85-2.71 \%$ day $^{-1}$, both of which were lower than the external control. A higher DGR from the selected strain $\left(1.77-2.74 \%\right.$ day $\left.^{-1}\right)$ compared to the internal control (1.15-1.25\% day $\left.{ }^{-1}\right)$ from the NTT strain was also observed, again both values were lower than the external control (3.33-3.95\% day $\left.{ }^{-1}\right)$. Statistical analysis of the three strains showed that strain selection significantly influenced $(\mathrm{P}<0.05)$ seaweed DGR. The selection technique used had increased DGR by up to $1.68 \%$ day $^{-1}$ compared to the internal control for three cycles of cultivation.

Pongmasak et al. (2014) reported that, during field studies implementing this selection procedure on the seaweed K. alvarezii in 2010 and 2012, the selected seaweed grew faster than the non-selected seaweed, with an increase of $15.0-41.7 \%$ in DGR. Fadilah et al. (2016) reported that seaweed $K$. alvarezii from selection exhibited higher growth rate as well as higher growth hormone (kinetin) level as $15.52 \%$ than internal control. Fahrur et al. (2019) reported that the seed selection of three varieties of K. alvarezii (Bali, Sirica, and Takalar) showed higher than that of control varieties. In different species, Parenrengi et al. (2016) reported that the DGR of selected seaweed $K$. striatum was significantly higher than control, in which DGR of seed from selected seaweed reached to $3.47 \%$ day $^{-1}$ while DGR of seed from control was $1.81 \%$ day $^{-1}$.

This study found that the Takalar strain had the highest DGR during the three cycles of cultivation. It is suspected that the Takalar strain has become adapted to local conditions over a long time. The lowest growth rate was obtained from the wild seaweed from NTT. Variation in DGR was also observed between cultivation cycles. The December period showed lower DGR compared to previous cycles. This is likely due to seaweed DGR being strongly related to environmental factors, including water quality. During this period, the Takalar strain could survive, however with reduced DGR. The Gorontalo and NTT strains had higher DGR for selected strains compared with the non-selected strains over the three cycles, however the DGR was still lower than the external (local cultivar) control.

Over the three cultivation cycle periods, the average growth rate of $K$. alvarezii obtained from selected Takalar and Gorontalo strains ranged from $2.95 \%$ day $^{-1}$ to $6.83 \%$ day $^{-1}$, which is comparable to rates reported for $K$. alvarezii from other sites: $2.5-3.5 \%$ day $^{-1}$ (Adnan \& Porse 1987), 4.0-11.0\% day ${ }^{-1}$ (Ohno et al. 1996), 1.1-3.4\% day $^{-1}$ (Hurtado-Ponce 1995), 0.2-4.2\% day ${ }^{-1}$ (Hurtado et al. 2001), 4.5-10.7\% day $^{-1}$ (Paula et al. 2002), 1.6-4.6\% day $^{-1}$ (Hung et al. 2009), 2.28-6.11\% day ${ }^{-1}$ (Thirumaran \& Anantharaman 2009) and 1.61-8.58\% day ${ }^{-1}$ (Orbita 2013). Recently, DGR ranging from $0.9-1.7 \%$ day $^{-1}$ was reported for seaweed cultivated in Parigi Moutong, Central Sulawesi (Muslimin et al. 2014).

Seaweed growth is seasonally affected by the environment, with different patterns in each cultivation area. Pongmasak et al. (2009) recommended that each 
cultivation area should have a seasonal planting calendar, to provide guidance for farmers in selecting suitable times for seaweed planting. In the Philippines, high $K$. alvarezii DGR coincides with the southwest monsoon or 'habagat' which is characterized by strong wave action, lower temperatures and low salinity brought by the wet monsoon (Orbita 2013). This result was contradicted with the studies by Hung et al. (2009) and Hurtado et al. (2001), in which the growth rate of $K$. alvarezii was minimal during the southwest monsoon. Meanwhile, minimal growth rates also occurred during the northeast monsoon or 'amihan', which is characterized by low water motion and high water temperature. In addition, 'ice-ice' disease was observed during the months of April-May. A study conducted by Pongmasak (2008) showed that the growth of seaweeds $K$. alvarezii and E. denticulatum was positively correlated with seawater nitrate and phosphate concentrations.
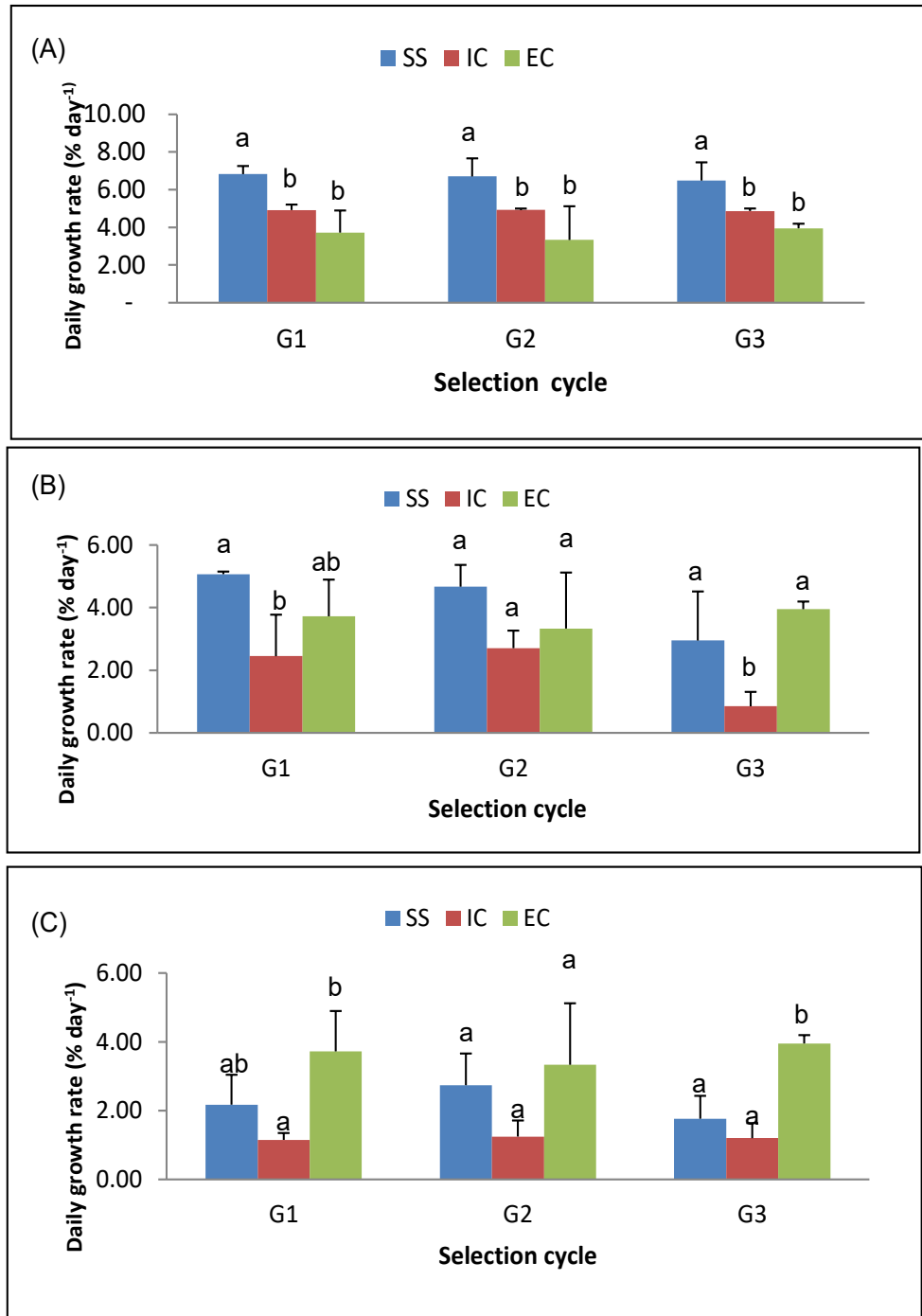

FIGURE 3. Daily growth rates of Takalar (A), Gorontalo (B) and NTT (C) strains for 30 days of cultivation cycles after performing the selection protocol $(\mathrm{G} 1=$ generation 1; G2=generation 2; G3=generation 3; $\mathrm{SS}=$ selected seaweed; IC=internal control; $\mathrm{EC}=$ external control; and small case letters $(\mathrm{a}, \mathrm{b})$ denote statistically different DGR values at the $95 \%$ confidence level $(\alpha=0.05)$ and error bars represent SD 


\section{CARRAGEENAN CONTENT AND GEL STRENGTH}

The Takalar and Gorontalo strains had relatively higher carrageenan content than the NTT strain (Figure 4). In general, carrageenan content of selected seaweeds was higher than that of the controls. Thus, it could be inferred that strain selection resulted in higher carrageenan content. The highest carrageenan content was obtained from the Gorontalo strain with values of $42.74 \%$ for selected seaweed and $42.98 \%$ for the internal control. The Takalar strain showed the highest relative increase (7.15\%) compared to the internal control, with average carrageenan content of $31.21 \%$ for the selected seaweed and $24.06 \%$ for the control. The NTT strain also showed a similar trend but the carrageenan content was lower than the other strains. Strain selection increased the NTT strain average carrageenan content by $6.58 \%$ (selected strain $18.74 \%$ and control $12.16 \%$ ). The overall average increase in carrageenan content between selected and control seaweeds was $4.7 \%$, which is equivalent to $28.1 \%$ of the total selection response. The t-student test showed a significant difference $(\mathrm{P}<0.05)$ in the carrageenan content of selected seaweed compared to the internal control for both Takalar and NTT strains, but the difference was not significant $(\mathrm{P}>0.05)$ for the Gorontalo strain.

Environmental factors also affect the growth and carrageenan content of $K$. alvarezii. Temperature, light intensity and nutrients are believed to be the most important factors affecting Kappaphycus growth. Orbita (2013) found that in Barangay Doña Consuelo, Ozamiz City, growth rate of $K$. alvarezii was strongly affected by nitrate concentration, while salinity had the greatest effect on the carrageenan content. In Vietnam and Mexico, the growth rate of $K$. alvarezii is strongly affected by water temperature. Meanwhile, the growth rate and carrageenan content of $K$. alvarezii in southeastern Brazil was highly affected by water temperature and salinity.

Among the three strains, the highest gel strength was obtained from the Gorontalo strain, followed by the Takalar and NTT strains. Gel strength of the selected Takalar strain $\left(472.15 \mathrm{~g} / \mathrm{cm}^{2}\right)$ was higher than that of the internal control $\left(376.48 \mathrm{~g} / \mathrm{cm}^{2}\right)$. On the other hand, the gel strength values of selected and internal control seaweeds were similar for both Gorontalo and NTT strains (Figure 5). The low gel strengths obtained from all strains were perhaps due to the analysis being conducted after a short cultivation time which is only 30 days, whereas the minimum recommended harvest time for these seaweeds is after 45 days of cultivation.

Correlation analysis of the pooled data for the three strains of seaweed showed a high correlation $\left(\mathrm{R}^{2}=0.821\right.$ or $\mathrm{r}=0.906$ ) between carrageenan content with gel strength of eucheumatoid seaweed cultivars. Meanwhile, the correlation between DGR and gel strength was $\mathrm{R}^{2}=0.3605$ or $\mathrm{r}=0.6000$; and the lowest correlation was between DGR and carrageenan content $\left(\mathrm{R}^{2}=0.0968\right.$ or $\mathrm{r}=0.3111$ ) (Figure $6)$. This study shows that when carrageenan content is higher, the gel strength of seaweed tends to be stronger. Parenrengi et al. (2016) reported that DGR had a strong correlation with carrageenan content $(\mathrm{r}=0.6604)$ and a low correlation with gel strength $(\mathrm{r}=0.1048)$ of seaweed K. striatum.

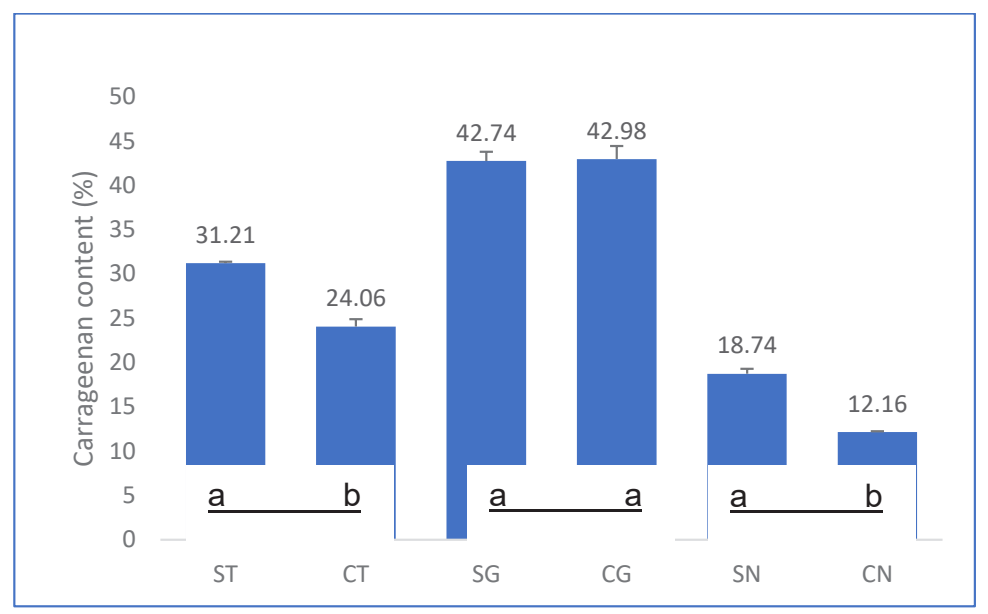

FIGURE 4. Carrageenan content of the seaweeds after cultivating each strain for the third 30 days of selection cycle ( $\mathrm{ST}=$ selected Takalar strain, $\mathrm{CT}=$ internal control of Takalar strain; $\mathrm{SG}=$ selected Gorontalo strain: $\mathrm{CG}=$ internal control of Gorontalo strain; SN=selected NTT strain; and CN=internal control of NTT strain), and small case letters $(a, b)$ denote statistically significant differences in carrageenan content at the $95 \%$ confidence level $(\alpha=0.05)$ and error bars represent SD 


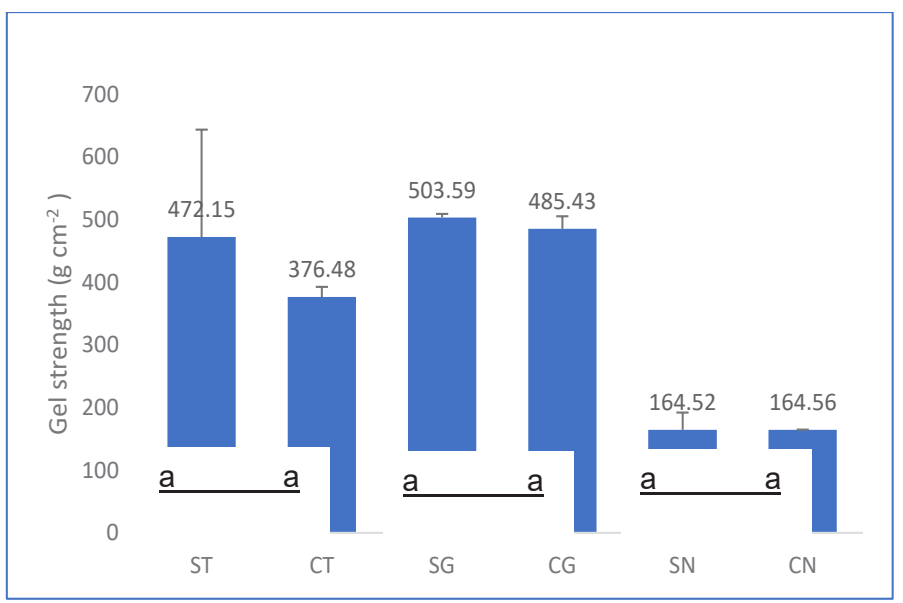

FIGURE 5. Gel strength of the seaweed strains after cultivating each strain for the third 30 days of selection cycle ( $\mathrm{ST}=$ selected Takalar strain, $\mathrm{CT}=$ Takalar strain internal control; $\mathrm{SG}=$ selected Gorontalo strain: $\mathrm{CG}=$ Gorontalo strain internal control; SN=selected NTT strain; and $\mathrm{CN}=\mathrm{NTT}$ strain internal control), and small case letters denote statistically different gel strength at the $95 \%$ confidence level $(\alpha=0.05)$ and error bars represent SD
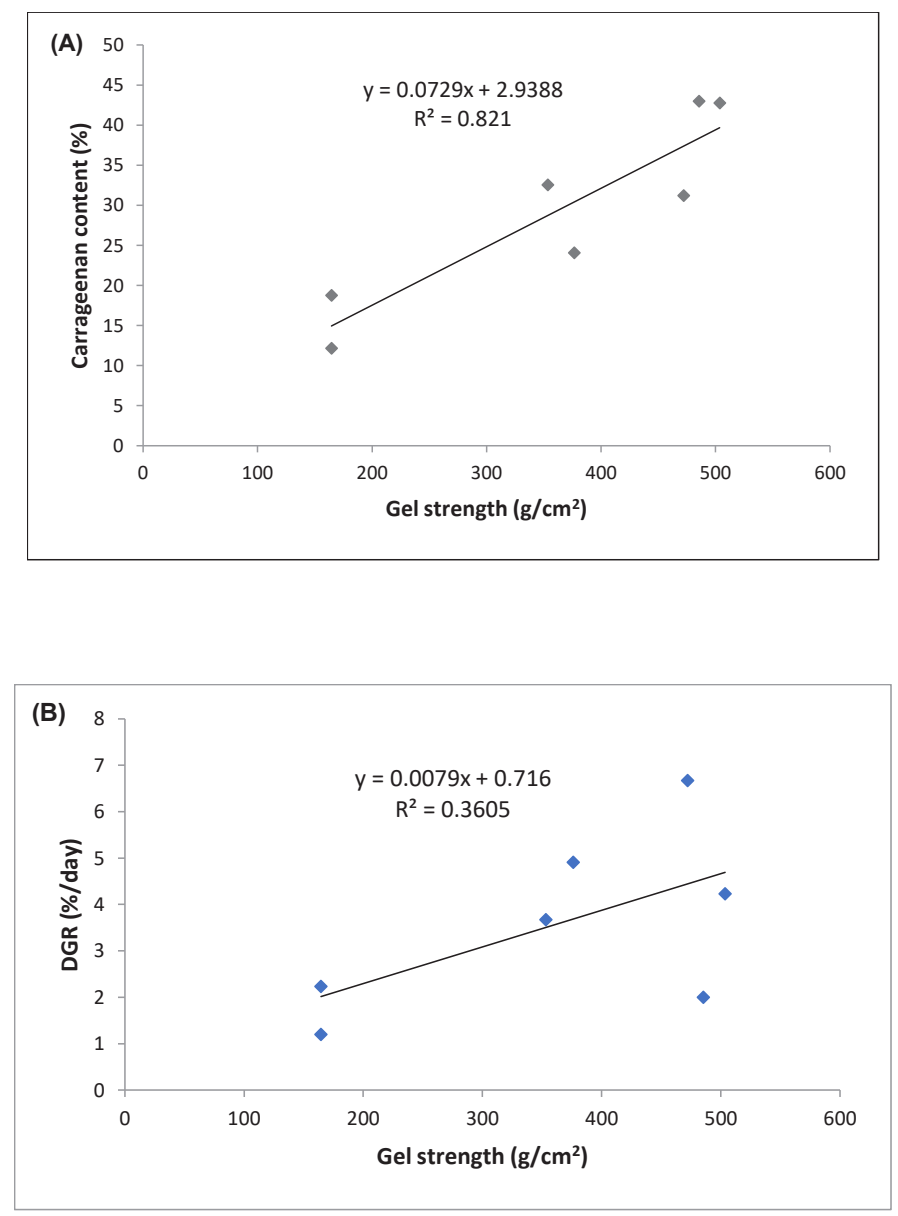


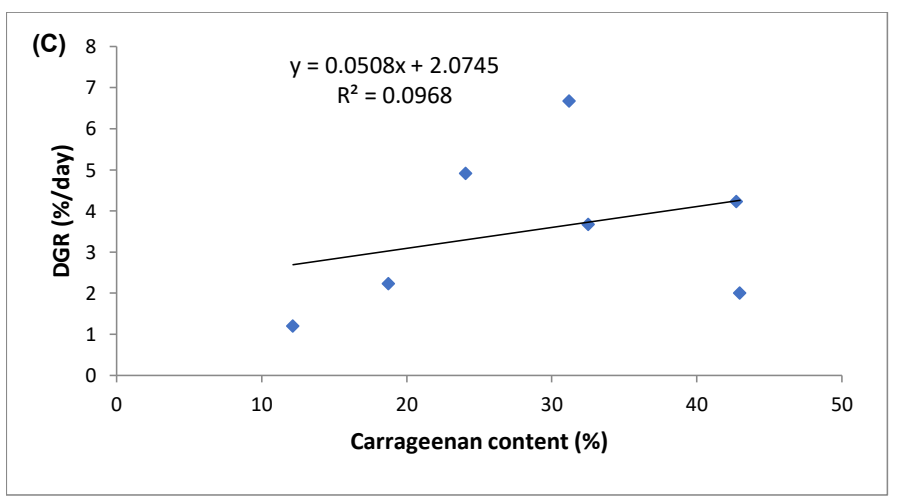

FIGURE 6. Correlation between carrageenan content and gel strength (A), daily growth rate and gel strength (B) and daily growth rate and carrageenan content $(\mathrm{C})$ of eucheumatoid seaweed species

\section{WATER QUALITY}

Nitrate concentration during the cultivation period ranged from $0.0588-1.8822 \mathrm{ppm}$, with ammonium concentrations of $0.0563-0.1875 \mathrm{ppm}$, nitrite concentrations of 0.0010 $0.1596 \mathrm{ppm}$, and phosphate concentrations of 0.0898 $0.1419 \mathrm{ppm}$. The $\mathrm{pH}$ range was $8.10-8.40$, and salinity range was $34.36-34.57 \mathrm{ppt}$. The maximum, minimum and standard deviation (SD) of all water quality parameters are listed in Table 1. Nitrate is the major source of nitrogen for all living organisms. Nitrate and phosphate concentrations play an important role in the growth of algae, including seaweeds. Nitrogen is considered as the primary limiting nutrient for algal growth in marine ecosystems. Thus, the success of seaweed cultivation requires knowledge of the nitrogen requirements of the algae being cultivated. In the absence of this nutrient, many algae present changes in shoot formation, a decrease in growth, soluble protein and phycobiliprotein contents, the nitrate, nitrite and amino acid contents of the thallus, photosynthesis, enzyme activities involved in carbon metabolism, and nitrate reductase activity (Martins et al. 2011). In this study, the average concentration of nitrate during the cultivation period was 0.0641-1.6169 ppm which is considered suitable for seaweed growth, based on the optimal nitrate concentration range of 0.9-3.5 ppm suggested by Atmadja et al. (1996). However, nitrate concentration was relatively low during cultivation cycles 1 and 2. The third cycle had a higher average nitrate concentration of $1.6169 \mathrm{ppm}$.

Phosphorus is another important nutrient, since it participates in the formation of biomolecules such as nucleic acids, proteins and phospholipids. However, the most important role is in energy transfer mediated by ATP and other high energy compounds present in photosynthesis and respiration. Phosphorus enrichment can stimulate the growth and the photosynthetic rates of some algae, as well as increase carrageenan production (Martins et al. 2011). In our study, the phosphate concentrations ranged from 0.0898 to $0.1419 \mathrm{ppm}$ during the cultivation period. Papalia (1997) stated that 0.1-3.5 ppm phosphate concentration is optimal for seaweed growth. This value is relatively close to the phosphate concentrations observed during the cultivation.

Our study found relatively similar salinity ranges of 34.36-34.57 ppt during the three selection cultivation cycles. Little work has been done on the growth or photosynthetic response of commercial eucheumatoids in relation to salinity. E. isiforme has been found to have a broad respirometric maximum at about $30-40$ ppt while $E$. uncinatum and $E$. denticulatum have a maximum at $30 \mathrm{ppt}$, and the photosynthetic maximum of $E$. isiforme occurred at 30-40 ppt depending on temperature (Ask \& Azanza 2002). They also reported that $E$. striatum cultivated in the laboratory did not survive beyond 7-14 days in salinities of less than 24 ppt or above 45 ppt. Pirzan and Tjaronge (2007) reported water quality parameter ranges in the seaweed cultivation areas around Sugi Island, Pangkajene Kepulauan (Pangkep), South Sulawesi including $\mathrm{pH}$ (8.4-8.5), nitrate (0.0013-0.0201 ppm), ammonia (0.0133$0.1690 \mathrm{ppm})$ and phosphate (0.0001-0.0119 ppm).

Pongmasak (2008) reported that the growth rate of seaweed $K$. alvarezii and E. denticulatum was influenced by seawater nitrate and phosphate concentrations. These water quality parameters were positively correlated with seaweed growth rate. A high correlation $(r>0.5)$ between seaweed carrageenan content and seawater nitrate and phosphate levels was also reported by Pongmasak and Tjaronge (2009). Seaweed cultivated in waters with 
high nitrate and phosphate concentrations had higher carrageenan content. Mulyaningrum et al. (2009) reported that higher seaweed carrageenan content was obtained at higher water temperature and transparency, with a strong positive correlation of $K$. alvarezii carrageenan content of seaweed with water temperature $(r=0.99)$ and transparency $(\mathrm{r}=0.79)$.

Based on the study conducted by Orbita (2013), the seasonal variations in growth rate and carrageenan yield can be related to seawater temperature and salinity, while water flow and inorganic phosphate levels can also influence carrageenan yield. The maximum growth and carrageenan yield both occurred during the southwest monsoon (June-September), coinciding with low water temperatures, low salinity, strong water movement and high nutrient concentrations. These results should be taken into consideration for the management of $K$. alvarezii. Afrianto and Liviawati (1989) reported that the optimum salinity for seaweed growth ranges from 30-35 ppt. Orbita (2013) stated that the temperature and salinity were the main environmental factors affecting the growth rates of $K$. alvarezii in most sampling sites. Average recorded seawater temperatures ranged from $27.67-30.72{ }^{\circ} \mathrm{C}$ with salinity of $23.60-29.80 \mathrm{ppt}$. It seems that temperatures in the range of $28-31{ }^{\circ} \mathrm{C}$ and salinity in the range of $24-30$ ppt are favorable for high growth rates of $K$. alvarezii. A negative correlation between temperature and growth rate of $K$. alvarezii has also been reported and likewise with salinity (Hung et al. 2009), seemingly consistent with the negative correlation between temperature and salinity in this study. Based on observations conducted June to September at Kolambugan, Philippines, Orbita (2013) concluded that maximum growth and carrageenan yield were obtained during the southwest monsoon (JuneSeptember) when water temperature and salinity were in the ranges of $28-31{ }^{\circ} \mathrm{C}$ and $24-30 \mathrm{ppt}$, respectively.

TABLE 1 . Water quality parameters observed during the seaweed cultivation study

\begin{tabular}{|c|c|c|c|c|}
\hline Parameters & Maximum & Minimum & Average & SD \\
\hline \multicolumn{5}{|c|}{ Nitrate (ppm) } \\
\hline -Cycles-1 & 0.0675 & 0.0588 & 0.0641 & 0.0047 \\
\hline -Cycles-2 & 0.4263 & 0.2069 & 0.2974 & 0.1146 \\
\hline -Cycles-3 & 1.8822 & 1.1455 & 1.6169 & 0.4093 \\
\hline \multicolumn{5}{|c|}{ Phosphate (ppm) } \\
\hline -Cycles-1 & 0.1224 & 0.0666 & 0.0898 & 0.0291 \\
\hline -Cycles-2 & 0.4072 & 0.2041 & 0.2887 & 0.1057 \\
\hline -Cycles-3 & 0.1559 & 0.1313 & 0.1419 & 0.0126 \\
\hline \multicolumn{5}{|l|}{$\mathrm{pH}$} \\
\hline -Cycles-1 & 8.12 & 8.10 & 8.10 & 0.02 \\
\hline -Cycles-2 & 8.29 & 8.10 & 8.22 & 0.10 \\
\hline -Cycles-3 & 8.40 & 8.40 & 8.31 & 0.16 \\
\hline \multicolumn{5}{|c|}{ Salinity (ppt) } \\
\hline -Cycles-1 & 34.52 & 34.43 & 34.36 & 0.21 \\
\hline -Cycles-2 & 34.60 & 34.45 & 34.52 & 0.08 \\
\hline -Cycles-3 & 34.60 & 34.52 & 34.57 & 0.04 \\
\hline
\end{tabular}

\section{CONCLUSION}

The implementation of strain selection during seaweed cultivation showed that this can be a useful method for the enhancement of seaweed growth rates. Moreover, this technique will be helpful in obtaining strains which are suitable for a specific location and for the future development of seaweed cultivation. To obtain the best performance, environment parameters at the seaweed cultivation site should be assessed. 


\section{ACKNOWLEDGEMENTS}

This research was funded by the ACIAR-RICA (Australia-Indonesia) collaborative research agreement SMAR-2008-025: Improved seaweed culture and postharvest waste utilization in South-East Asia. We would also like to thank all the researchers and technicians at Research Institute for Brackish Water Aquaculture and Fisheries Extension who supported this study.

\section{REFERENCES}

Adnan, H. \& Porse, H. 1987. Culture of Eucheuma cottonii and Echeuma spinosum in Indonesia. Hydrobiologia 151: 355-358.

Afrianto, E. \& Liviawati, E. 1989. Budidaya Rumput Laut dan Cara Pengolahannya. Jakarta: Bhratara Niaga Media.

Amini, S. \& Parenrengi, A. 1995. Pengaruh variasi komposisi pupuk terhadap pertumbuhan rumput laut Eucheuma cottonii pada kultur in-vitro. Jurnal Penelitian Perikanan Indonesia 1(3): 47-54.

Ask, E.A. \& Azanza, R.V. 2002. Advances in cultivation technology of commercial eucheumatoid species: A review with suggestions for future research. Aquaculture 206(3-4): 257-277.

Atmadja, W.S., Kadi, A., Sulistidjo, S. \& Safari, R. 1996. Pengenalan Jenis-jenis Rumput Laut Indonesia. Jakarta: Puslitbang Oseanografi LIPI.

Erlania, E. \& Radiarta, I.N. 2014. Management of sustainable seaweed (Kappaphycus alvarezii) aquaculture in the context of climate change mitigation. Indonesian Aquaculture Journal 9(1): 65-72.

Fadilah, S., Alimuddin, A., Pongmasak, P.R., Santosa, J. \& Parenrengi, A. 2016. Growth, morphology and growth related hormone level in Kappaphycus alvarezii produced by mass selection in Gorontalo Waters, Indonesia. HAYATI Journal of Biosciences 23(1): 29-34.

Fahrur, M., Parenrengi, A., Makmur, M. \& Mulyaningrum, S.R.H. 2019. Performa rumput laut Kappaphycus alvarezii hasil seleksi di perairan Laikang Kabupaten Takalar. Media Akuakult 14(1): 9-18.

FAO. 2018. The State of World Fisheries and Aquaculture 2018 - Meeting the Sustainable Development Goals. Rome: Food and Agriculture Organization of the United Nations.

Food Machinery Corporation (FMC). 1977. Carrageenan Marine Colloid. Monograph Number One, Marine Colloid Division FMC Corporation, New Jersey: Springfield.

Hadie, L.E. \& Hadie, W. 2012. Evaluasi perkembangan budidaya rumput laut dalam mendukung industrialiasasi perikanan. In Prosiding Seminar Nasional Kelautan VIII), edited by Taufiqurrohman, M., Prayogi, U. \& Winarno, A. Surabaya: Hang Tuah University. pp. 32-38.

Hasnawi, H., Makmur, M., Paena, M. \& Mustafa, A. 2013. Analisis kesesuaian lahan budidaya rumput laut (Kappaphycus alvarezii) di Kabupaten Parigi Moutong, Provinsi Sulawesi Tengah. Jurnal Riset Akuakultur 8(3): 493-505.

Hung, L., Hori, K., Nang, H., Kha, T. \& Hoa, L.T. 2009. Seasonal changes in growth rate, carrageenan yield and lectin content in the red alga Kappaphycus alvarezii cultivated in Camranh Bay, Vietnam. Journal of Applied Phycology 21: 265-272.
Hurtado-Ponce, A.Q. 1995. Carrageenan properties and proximate composition of three morphotypes of Kappaphycus alvarezii Doty (Gigartinales, Rhodophyta). Botanica Marina 38(1-6): 215-219.

Hurtado, A.Q., Agbayani, R., Sanares, R. \& Castro-Mallare, M. 2001. The seasonality and economic feasibility of cultivating Kappaphycus alvarezii in Panagatan Cays, Caluya, Antique, Philippines. Aquaculture 199(3-4): 295-310.

Lideman, L., Laining, A., Nishihara, G.N. \& Terada, R. 2014. Effect of temperature and light on the photosynthesis as measured by chlorophyll fluorescence of cultured Kappaphycus sp. (Sakol strain) from Indonesia. Indonesian Aquaculture Journal 8(2): 163-171.

Martins, A.P., Junior, O.N., Colepicolo, P. \& Yokoya, N.S. 2011. Effects of nitrate and phosphate availabilities on growth, photosynthesis and pigment and protein contents in colour strains of Hypnea musciformis (Wulfen in Jacqu.) J.V. Lamour. (Gigartinales, Rhodophyta). Revista Brasileira de Farmacognosia 21(2): 1-18.

Mulyaningrum, S.R.H., Parenrengi, A., Risjani, Y. \& Nursyam, H. 2013. Formulasi auksin (indole acetic acid) dan sitokinin (kinetin, zeatin) untuk morfogenesis serta pengaruhnya terhadap pertumbuhan, sintasan dan laju regenerasi kalus rumput laut, Kappaphycus alvarezii. Jurnal Riset Akuakultur 8(1): 31-41.

Mulyaningrum, S.R.H., Pongmasak, P.R. \& Suryati, E. 2009. Kandungan karagenan enam strain rumput laut Kappaphycus alvarezii di perairan Polewali Mandar, Sulawesi Barat. In Prosiding Forum Inovasi Teknologi Akuakultur, edited by Sudradjat, A., Supriyadi, H., Hanafi, A., Kristanto, A.H., Chumaidi, Mustafa, A., Imron \& Insan, I. Jakarta: Pusat Riset Perikanan Budidaya. pp. 766-771.

Muslimin, Pongmasak, P.R. \& Adhiyudarto, B. 2014. Pengamatan pertumbuhan rumput laut Kappaphycus alvarezii dengan metode long line di Perairan Parigi Moutong Provinsi Sulawesi Tengah. In Prosiding Forum Inovasi Teknologi Akuakultur, edited by Sugama, K., Kusnendar, E., Rachmansyah, Giri, N.A., Yuhana, M., Kristanto, A.H., Imron, Radiarta, I.N. \& Dewi, R.R.S.P.S. Jakarta: Pusat Riset Perikanan Budidaya. pp. 145-153.

Mustafa, A., Tarunamulia, T., Hasnawi, H. \& Radiarta, I.N. 2017. Karakteristik dan kesesuaian perairan untuk budidaya rumput laut di Kabupaten Kepulauan Sangihe, Sulawesi Utara. Jurnal Riset Akuakultur 12(2): 187-196.

Ohno, M., Nang, H.Q. \& Hirase, S. 1996. Cultivation and carrageenan yield and quality of Kappaphycus alvarezii in the waters of Vietnam. Journal of Applied Phycology 8: 431-437.

Orbita, M.L.S. 2013. Growth rate and carrageenan yield of Kappaphycus alvarezii (Rhodophyta, Gigartinales) cultivated in Kolambugan, Lanao del Norte, Mindanao, Philippines. AAB Bioflux 5(3): 128-139.

Paena, M., Hasnawi \& Mustafa, A.A. 2010. Analisis data dukung strategi pengembangan budidaya rumput laut di perairan pesisir Kabupaten Mamuju, Provinsi Sulawesi Barat. In Prosiding Forum Inovasi Teknologi Akuakultur, edited by Sudradjat, A., Rachmnasyah, Hanafi, A., Azwar, Z.I., Imron, I., Kristanto, A.H., Chumaidi, C. \& Insan, I. Jakarta: Pusat Penelitian dan Pengembangan Perikanan Budidaya. pp. 1129-1137. 
Papalia, S. 1997. Pengaruh konsentrasi fitohormon auksin dan lama waktu perendaman terhadap laju pertumbuhan dan mutu rumput laut (Eucheuma cottonii). Hasanuddin University, Ph.D. Thesis (Unpublished).

Parenrengi, A. 2013. Seaweed culture in Indonesia. Paper presented at Indonesia-FAO Regional Workshop on Seaweed Culture, Handling, and Processing Jakarta, October: 3-6.

Parenrengi, A., Fahrur, M., Makmur, M. \& Mulyaningrum, S.R.H. 2016. Seleksi rumput laut Kappaphycus striatum dalam upaya peningkatan laju pertumbuhan bibit untuk budidaya. Jurnal Riset Akuakultur 11(3): 235-248.

Parenrengi, A., Sulaeman, Suryati, E. \& Tenriulo, A. 2007. Genetic characteristic of seaweed Gracilaria verrucosa at different locations. Aquacultura Indonesiana 8(3): 177-182.

Parenrengi, A., Sulaeman, Suryati, E. \& Tenriulo, A. 2006. Karakterisasi genetika rumput laut Kappaphycus alvarezii yang dibudidayakan di Sulawesi Selatan. Jurnal Riset Akuakultur 1(1): 01-11.

Paula, E.J., Pereira, R.T.L. \& Ohno, M. 2002. Growth rate of the carrageenophyte Kappaphycus alvarezii (Rhodophyta, Gigartinales) introduced in subtropical waters of São Paulo State, Brazil. Phycological Research 50(1): 1-9.

Pirzan, A.M. \& Tjaronge, M. 2007. Studi budidaya rumput laut di pulau Saugi Kabupaten Pangkep, Sulawesi Selatan. In Prosiding Seminar Nasional Kelautan III, edited by Taufiqurrohman, M., Prayogi, U., Giman, G. \& Winanro, A. Surabaya: Hang Tuah University. p. 4348.

Pongmasak, P.R. 2010. Pencegahan hama dan penyakit rumput laut Kappaphycus alvarezii. In Prosiding Seminar Nasional Perikanan Indonesia, edited by Syamsuddin, S., Sipahutar, Y.H., Safurridjal, Basith, A., Nurbani, S.Z., Suharto, Siregar, A.N., Rahardjo, S., Surya, R. \& Sanofa, V. pp. 447-454.

Pongmasak, P.R. 2008. Hubungan ketersediaan nitrogen dan fosfat dalam perairan terhadap pertumbuhan rumput laut di Kabupaten Bantaeng, Sulawesi Selatan. In Prosiding Seminar Nasional Perikanan Indonesia, edited by Permadi, A., Sipahutar, Y.H., Saifurridjal, Basith, A., Sugriwa, E., Siregar, A.N., Thaib, E.A. Puwanto, P. \& Sanofa, V. pp. 640-647.

Pongmasak, P.R. \& Tjaronge, M. 2010. Performansi pertumbuhan dan kandungan karaginan rumput laut, Kappaphycus alvarezii dengan aplikasi budidaya vertikultur. In Prosiding Seminar Nasional Perikanan Indonesia, edited by Syamsuddin, S., Sipahutar, Y.H., Safurridjal, Basith, A., Nurbani, S.Z., Suharto, Siregar, A.N., Rahardjo, S., Surya, R. \& Sanofa, V. pp. 434-438.

Pongmasak, P.R. \& Tjaronge, M. 2009. Hubungan kandungan nitrogen dan fosfor pada perairan berbeda dengan kandungan karaginan rumput laut, Kappaphycus alvarezii. In Prosiding Forum Inovasi Teknologi Akuakultur, edited by Sudradjat, A., Supriyadi, H., Hanafi, A., Kristanto, A.H., Chumaidi, Mustafa, A., Imron, I. \& Insan, I. pp. 1165-1171.

Pongmasak, P.R., Kristanto, A.H., Kusdiarti, K. \& Kusnendar, E. 2014. Peningkatan produktivitas dan keuntungan budidaya rumput laut Kappaphycus alvarezii menggunakan bibit unggul hasil seleksi varietas. In Prosiding Forum Inovasi Teknologi Akuakultur, edited by Sugama, K., Kusnendar, E., Rachmansyah, R., Giri, N.A., Yuhana, M., Kristanto, A.H., Imron, I., Radiarta, I.N. \& Dewi, R.R.S.P.S. pp. 123-135.
Pongmasak, P.R., Sahrijannah, A. \& Septiningsih, E. 2013. 2013. Penentuan "cut off" seleksi varietas untuk produksi unggul rumput laut Gracillaria verrucosa cepat tumbuh. Prosiding Seminar Nasional Tahunan X Hasil Penelitian Kelautan dan Perikanan. Jogjakarta: Universitas Gajah Mada. pp. 1-9.

Pongmasak, P.R., Parenrengi, A., Tjaronge, M. \& Rusman. 2011. Protokol - Seleksi Varietas Bibit Unggul Rumput Laut, edited by Rachmansyah, R. \& Suryati, E. Jakarta: Research Institute for Coastal Aquaculture, Center for Fisheries Research, Agency for Marine \& Fisheries Research, Indonesian Ministry of Maritime Affairs and Fisheries.

Pongmasak, P.R., Asaad, A.I.J., Hasnawi, Pirzan, A.M. \& Lanuru, M. 2010. Analisis kesesuaian lahan untuk pengembangan budidaya rumput laut di Gusung Batua, Pulau Badi, Kabupaten Pangkep, Sulawesi Selatan. Jurnal Riset Akuakultur 5(2): 299-316.

Porse, H. \& Rudolph, B. 2017. The seaweed hydrocolloid industry: 2016 updates, requirements, and outlook. Journal of Applied Phycology 29: 2187-2200.

Priyono, B. \& Andriyatno, S. 2012. Strategi dan kebijakan pengembangan rumput laut di Kabupaten Brebes, Jawa Tengah. In Prosiding Indoaqua-Forum Inovasi Teknologi Akuakultur, edited by Haryanti, Rachmansyah, Sugama, K., Parenrengi, A., Sudradjat, A., Imron, Sunarto, A, Sumiarsa, G.S., Azwar, Z.I. \& Kristanto, A.H. Jakarta: Agency for Marine and Fisheries Research and Development. pp. 1405-1412.

Radiarta, I.N., Saputra, A. \& Albasri, H. 2012. Pemetaan kelayakan lahan budidaya rumput laut (Kappaphycus alvarezii) di Kabupaten Bintan Provinsi Kepulauan Riau dengan pendekatan sistem informasi geografis dan penginderaan jauh. Jurnal Riset Akuakultur 7(1): 145-157.

Rajamuddin, M.A., Jaya, A.A., Ridwan \& Suryati, E. 2010. Kajian induksi kalus rumput laut Kappaphycus alvarezii untuk produksi embrio somatik. Jurnal Riset Akuakultur 5(2): 211-219.

Suhaimi, R.A., Makmur, \& Mustafa, A.S. 2012. Evaluasi kesesuaian lahan untuk budidaya rumput laut (Kappaphycus alvarezii) di kawasan pesisir Kabupaten Pohuwato Provinsi Gorontalo. In Prosiding IndoaquaForum Inovasi Teknologi Akuakultur, edited by Haryanti, Rachmansyah, Sugama, K., Parenrengi, A., Sudradjat, A., Imron, Sunarto, A., Sumiarsa, G.S., Azwar, Z.I. \& Kristanto, A.H. Jakarta: Agency for Marine and Fisheries Research and Development. pp. 827-840.

Sulaeman, S., Parenrengi, A., Suryati, E. \& Rosmiati, R. 2007. Genetic, coloration and growth performance of two different varieties of Kappaphycus alvarezii. Indonesian Aquaculture Journal 2(1): 23-26.

Suryati, E., Rosmiati, Parenrengi, A. \& Tenriulo, A. 2015. In vitro growth rate of Kappaphycus alvarezii micropropagule and embryo by enrichment medium with seaweed extract. Indonesian Aquaculture Journal 10(1): 13-17.

Suryati, E., Puspaningtyas, L., Widyastuti, U. \& Suharsono. 2013. Karakteristik genetik Kappaphycus alvarezii sehat dan terinfeksi penyakit Ice-Ice dengan metode Amplified Fragment Length Polymorphism (AFLP). Jurnal Riset Akuakultur 8(1): 21-31. 
Suryati, E., Tenriulo, A. \& Mulyaningrum, S.R.H. 2007. Isolasi dan kultur protoplas rumput laut Kappaphycus alvarezii di laboratorium. Jurnal Riset Akuakultur 2(3): 399-405.

Thirumaran, G. \& Anantharaman, P. 2009. Daily growth rate of field farming seaweed Kappaphycus alvarezii (Doty) Doty ex P. Silva in Vellar Estuary. World Journal of Fish and Marine Sciences 1(3): 144-153.

Andi Parenrengi*, Rachman Syah \& Mat Fahrur Research Institute for Brackish Water Aquaculture and Fisheries Extension, Maros

Indonesia

Andi Parenrengi*

Center of Excellence for Development and Utilization of Seaweed (CEDUS), Makassar Indonesia
Symon Dworjanyn

National Marine Science Centre

Southern Cross University

Australia

Petrus Rani Pongmasak

Research Institute for Seaweed Culture

Gorontalo

Indonesia

*Corresponding author; email: andi_parenrengi@hotmail.com

Received: 4 February 2020

Accepted: 12 May 2020 